\title{
Pengaturan dan Akibat Hukum Tidak Dilaksanakanya Putusan Peradilan Adat Dayak
}

\author{
Citranu \\ Institut Agama Hindu Negeri Tampung Penyang Palangka Raya, Jl. G. Obos X, \\ Palangka Raya, 74874, Indonesia; \\ Email: ranu.justitia@gmail.com
}

\begin{abstract}
Abstrak
Kajian ini bertujuan untuk mengetahui pengaturan pelaksanaan eksekusi putusan peradilan adat dayak dan akibat hukum dari tidak dilaksanakannya putusan adat dayak, agar kedepannya dapat merumuskan pengaturan eksekusi putusan peradilan adat dayak yang berkeadilan dan dapat diterima oleh semua orang. Tulisan ini menggunakan metode hukum normatif. Kajian ini dilandasi adanya kekosongan hukum terkait sanksi atau akibat hukum tidak dilaksanakannya putusan adat dayak. Hasil dari kajian ini bahwa pengaturan eksekusi terhadap putusan peradilan adat dayak tidak diatur secara jelas di dalam perjanjian Tumbang Anoi, melainkan dalam bentuk aturan tidak tertulis sesuai dengan nilai kepatutan menurut masyarakat adat dayak yakni Belom Bahadat. Selama ini eksekusi terhadap putusan peradilan adat dayak dilakukan dengan suka rela dengan tidak ada paksaan terhadap pihak yang dijatuhi hukuman sedangkan akibat hukum dari tidak dilaksanakannya putusan peradilan adat dayak adalah si terhukum atau pihak yang dikenakan sanksi adat dayak secara jasmani akan dikucilkan dan dianggap rendah beserta keturunannya karena tidak melaksanakan putusan adat dan dapat di laporkan pidana atau dapat digugat secara perdata karena telah melecehkan peradilan adat, sedangkan secara rohaninya menurut kepercayaan adat dayak, pihak yang dikenakan sanksi akan mendapatkan kesulitan hidup di dunia dan kehidupan setelah kematian.
\end{abstract}

Kata Kunci: putusan adat, sanksi, dayak

\section{The Regulation and legal consequences of not implementing of Dayak Adat Judicial Decisions}

\begin{abstract}
This study aims to determine the arrangements for implementing the execution of Dayak adat judicial decisions and the legal consequences of not implementing Dayak adat decisions, so that in the future it can formulate arrangements for the execution of Dayak adat judicial decisions that are fair and can be accepted by everyone. This paper uses the normative legal method. This study is based on the existence of a legal vacuum related to sanctions or the legal consequences of not implementing a Dayak adat ruling. The result of this study is that the execution arrangements for the Dayak Adat court decisions are not clearly regulated in the Tumbang Anoi agreement, but in the form of unwritten rules according to the propriety values according to the Dayak Adat people namely Belom Bahadat. The execution of Dayak adat judicial decisions is done voluntarily with no coercion on the party sentenced while the legal consequences of not implementing the Dayak adat court verdict are the convicted or the party subject to Dayak adat sanctions
\end{abstract}


will be physically ostracized and considered inferior and their offspring because they do not implement Adat decisions and can be reported criminally or can be sued civilly because they have abused Adat justice, while spiritually according to Dayak Adat beliefs, those who are sanctioned will have difficulty living in the world and life after death.

Keywords: adat decisions, sanctions, dayak

\section{A. Pendahuluan}

Masyarakat adat dayak mengenal hukum sudah sejak lama, kehidupan masyarakat adat dayak selalu hidup berdasarkan prinsif nilai-nilai hukum dan adat istiadat yang dipertahankan secara turun temurun dari nenek moyang. Keberadaan masyarakat adat diakui di dalam konstitusi sebagaimana Pasal 18 B ayat (2) UUD RI 1945 Negara mengakui dan menghormati kesatuan-kesatuan masyarakat hukum adat beserta hak-hak tradisionalnya sepanjang masih hidup dan sesuai dengan perkembangan masyarakat dan prinsip Negara Kesatuan Republik Indonesia, yang diatur dalam undang-undang. Keberadaan msyarakat hukum adat menurut Undang-Undang Nomor 5 Tahun 1960 tentang Peraturan Dasar PokokPokok Agraria diakui keberadaannya sepanjang masih ada sesuai Pasal 3 yang berbunyi: pelaksanaan hak ulayat dan hak-hak yang serupa itu dari masyarakatmasyarakat hukum adat, sepanjang menurut kenyataannya masih ada, harus sedemikian rupa sehingga sesuai dengan kepentingan nasional dan Negara, yang berdasarkan atas persatuan bangsa serta tidak boleh bertentangan dengan Undangundang dan peraturan-peraturan lain yang lebih tinggi. Keberadaan masyaraat hukum adat ditur pada ketentuan Pasal 6 ayat (2) UU No. 39 Tahun 1999 tentang Hak Asasi Manusia yang berbunyi: Identitas budaya masyarakat hukum adat, termasuk hak atas tanah ulayat dilindungi, selaras dengan perkembangan zaman. Pasal 1 ayat 31 Undang-Undang No 32 Tahun 2009 tentang Perlindungan dan Pengelolaan Lingkungan Hidup, memberikan definisi masyarakat hukum adat adalah kelompok masyarakat yang secara turun temurun bermukim di wilayah geografis tertentu karena adanya ikatan pada asal usul leluhur, adanya hubungan yang kuat dengan lingkungan hidup, serta adanya sistem nilai yang menentukan pranata ekonomi, politik, sosial, dan hukum. Pasal 67 ayat (1) Undang-Undang 41 tahun 1999 tentang Kehutanan, keberadaan masyarakat hukum adat Masyarakat hukum adat sepanjang menurut kenyataannya masih ada dan diakui keberadaannya. Pada penjelasan Pasal 67 ayat (1) Masyarakat hukum adat diakui keberadaannya, jika menurut kenyata-annya memenuhi unsur antara lain: a. masyarakatnya masih dalam bentuk paguyuban (recht-gemeenschap), b. ada kelembagaan dalam bentuk perangkat penguasa adatnya, c. ada wilayah hukum adat yang jelas, d. ada pranata dan perangkat hukum, khususnya peradilan adat, yang masih ditaati, dan e. masih mengadakan pemungutan hasil hutan di wilayah hutan sekitarnya untuk pemenuhan kebutuhan hidup sehari-hari.

Hukum adat dayak beserta kelembagaan adat dayak dalam hal ini Kedamangan merupakan instrumen yang mendukung hukum adat dayak yang dipertahankan secara turun temurun oleh masyarakat adat dayak dan sampai sekarang masih berlaku di wilayah pulau Kalimantan. Masyarakat hukum adat dayak memiliki hukum adat, adanya masyarakat adat dayak, memiliki 
kelembagaan adat dayak yakni Kedamangan, dan memiliki wilayah hukum adat. Kelembagaan adat dayak kemudian diatur dalam ketentuan Peraturan Daerah Provinsi Kalimantan Tengah Nomor 16 Tahun 2008 tentang Kelembagaan Adat Dayak Di Kalimantan Tengah. Pada dasarnya peraturan daerah memengakomodir keberadaan masyarakat hukum adat yang ada di Kalimantan Tengah agar sesuai dengan peraturan perundang-undangan yang ada di Indonesia, walaupun secara materil keberadaan masyarakat hukum adat dan kelembagaan adat dayak sudah ada sejak lama ada jauh sebelum Indonesia merdeka.

Hukum adat dayak tidak bersifat tertulis, melainkan hidup dan berkembang secara alami yang tercermin di dalam nilai tata kehidupan melalui perilaku masyarakat adat dayak. Hukum yang berkembang lebih cenderung kepada moralitas dan penilaian akan perbuatan baik dan buruk, bagi pihak yang menjalankan kehidupan sesuai dengan hukum adat dayak maka itu merupakan suatu penghormatan terhadap hukum dan keyakinan masyarakat adat dayak, karena hukum adat dayak erat kaitannya dengan keyakinan masyarakat adat dayak terhadap Tuhan yang maha kuasa. Bagi pihak yang melanggar hukum adat dayak maka akan diadili dan dihadapkan kepada kepala adat untuk diadili atau untuk mendapatkan hukuman ataupun solusi dari sengketa adat yang terjadi melalui keputusan adat. Peradilan adat dayak merupakan peradilan yang sudah sejak lama ada di lingkungan masyarakat adat dayak, akan tetapi istilahnya dulu tidak menggunakan istilah peradilan melainkan istilah Kedamangan.

Kedamangan merupakan lembaga adat dayak yang melaksanakan fungsi peradilan. ${ }^{1}$ Kedamangan memiliki wilayah masing-masing yang tersebar di seluruh wilayah Kalimantan beberapa diantaranya seperti Kedamangan Pahandut yang memiliki wilayah hukum di kecamatan Pahandut dan Kedamangan Jekan Raya yang membawahi wilayah hukum adat kecamatan Jekan Raya yang sebagian besar wilayahnya berada di dalam kota Palangka Raya. Kedamangan memiliki tugas dan fungsi sebagai lembaga peradilan adat dayak untuk menyelesaikan permasalahan adat berdasarkan hukum adat dayak yang terdapat di dalam 96 Pasal Perjanjian Damai Tumbang Anoi 1894 dan prinsif-prinsif dasar hukum adat dayak yang bersifat tidak tertulis akan tetapi tetap dipertahankan sampai sekarang. Keputusan adat yang dikeluarkan oleh Kedamangan merupakan putusan yang bersifat mengikat dan harus dilaksanakan oleh siapa saja yang telah diadili dan dihukum untuk menjalankan keputusan adat, akan tetapi seiring berjalannya waktu keputusan adat ini tidak serta merta berjalan lancar, bisa saja dikemudian hari adanya perlawanan atau pengingkaran terhadap keputusan adat, misalnya dengan tidak menjalankan keputusan adat, sehingga keputusan adat tersebut tidak memiliki kekuatan memaksa terhadap pihak yang diadili atau dihukum menggunakan hukum adat dayak, karena sebagaimana diketahui selama ini

\footnotetext{
1 Y. Nathan Ilon, Ilustrasi Dan Perwujudan Lambang Batang Garing Dan Dandang Tingang Sebuah Konsepsi Memanusiakan Manusia Dalam Filsafat Suku Dayak Ngaju Kalimantan Tengah. Kapuas: Pemerintah Kabutaten Tingkat II Kapuas, 1987, hal. 107-108
} 
putusan adat dayak yang dikeluarkan oleh lembaga Kedamangan selalu dijalankan secara suka rela oleh para pihak yang bersengketa atau pihak yang dihukum.

Konsep pengaturan eksekusi terhadap putusan peradilan adat ke depannya sangat dibutuhkan agar bisa merespon keadaan dan permasalahan yang ada pada masyarakat dayak, sebagaimana hukum yang dicita-citakan yang berlaku dimasa yang akan datang (ius constituendum) ${ }^{2}$. Hal ini sangat penting agar putusan adat dayak tidak semata mengharapkan pelaksanaan putusan secara suka rela dari pihak yang di hukum, atau dari pihak yang berperkara tapi memiliki upaya paksa atau upaya eksekutorial seperti halnya negara ${ }^{3}$ memiliki daya paksa agar masyarakat taat terhadap hukum, karena hukum tidak hanya diatas kertas saja melainkan hukum berfungsi sebagai pelindung kepentingan masyarakat dan menciptakan ketertiban tatanan di dalam masyarakat. ${ }^{4}$ Ketaatan terhadap hukum dipengaruhi oleh keberadaan ketentuan hukum, yang memiliki subtansi hukum yang sesuai dengan harapan dan melingkupi aspek kehidupan masyarakat adat dayak. Keberadaan ketentuan hukum adat terkait harus adanya sanksi tegas bagi pihak yang tidak mentaati putusan adat sangat penting guna memberikan kepastian hukum.

Pada dasarnya kasus yang terjadi untuk sementara masih belum ada sebagaimana dipaparkan oleh Damang Pahandut dan Damang Jekan Raya, akan tetapi karena perkembangan zaman dan interaksi sosial di dalam masyarakat semakin kompleks, bukan tidak mungkin terjadi adanya penolakan terhadap putusan adat dayak. Sebagai contoh adanya penyebaran paham radikalisme kemudian pihak yang menyebarkan paham radikal tersebut dihukum berdasarkan hukum adat dayak karena melanggar Pasal 96 tentang prinsif Belom Bahadat dan mengganggu rasa kesatuan sebagaimana prinsif Huma Betang, selanjutnya pelaku diperintahkan untuk menghentikan penyebaran paham terlarang tersebut, membayar Singer (istilah denda menurut hukum adat dayak), dan pelaku diwajibkan untuk melaksanakan ritual adat untuk pembersihan atau penyucian terhadap pelanggaran yang sudah dilakukan, sebaliknya pihak pelaku bersikukuh bahwa paham yang diajarkan dan disebar luaskannya bukan merupakan paham radikal tetapi telah sesuai dengan suatu ajaran agama tertentu sehingga tidak mau mematuhi putusan adat. Penolakan seperti ini yang harus diantisipasi oleh pihak Kedamangan agar kedepannya pelaksanaan eksekusi dapat berjalan dengan lancar dan eksekusi putusan adat dayak dapat dipatuhi serta memiliki kekuatan hukum eksekutorial. Putusan adat dayak yang dijalankan pastinya bertujuan untuk penegakan hukum adat dayak dan memberikan kemanfaatan bagi masyarakat adat dayak, apabila putusan peradilan adat dayak dapat dilaksanakan dengan baik maka melahirkan kerukunan, terjaganya rasa kesatuan dan persatuan serta terciptanya rasa aman dan damai di dalam masyarakat adat dayak.

\footnotetext{
${ }^{2}$ Sudikno Mertokusumo, Penemuan Hukum Sebuah Pengantar, Yogyakarta: Liberty, 2007, hal. 120.

${ }^{3}$ I Dewa Gede Atmadja, Filsafat Hukum Dimensi Tematis Dan Historis. Malang: Setara Press, 2013, hal 110.

${ }^{4}$ Sudikno Mertokusumo, Teori Hukum (Edisi Revisi), Jogjakarta: Cahaya Atma, 2012, hal. 44.
} 
Kajian ini mempermasalahkan pengaturan eksekusi putusan peradilan adat dayak untuk masa sekarang dan masa yang akan datang serta akibat hukum apabila tidak dilaksanakannya putusan adat dayak tersebut. Maka tidak berlebihan kiranya penulis mengkaji bagaimana pengaturan ke depannya terkait pelaksanaan eksekusi putusan adat dayak untuk mengisi kekosongan hukum atau ketiadaan peraturan dan apa yang menjadi akibat hukum terhadap pihak yang dihukum atau yang diadili dan tidak mematuhi keputusan adat dayak, karena sampai sekarang masih belum ada yang mengkajinya. Tujuan kajian ini adalah untuk merumuskan atau memperbaharui pengaturan hukum adat dayak yang memiliki kekosongan terkait pelaksanaan atau eksekusi terhadap putusan adat atau putusan Kedamangan dan sanksi serta akibat hukum yang terjadi kepada pelaku apabila tidak melaksanakan putusan adat dayak.

Adapun beberapa tulisan yang pernah mengkaji tentang hukum adat dayak meliputi: Sri Ismawati", mengkaji tentang "Mekanisme Penyelesaian Perkara Anak Yang Berhadapan Dengan Hukum Pada Masyarakat Dayak Kanayatn (Kajian Perbandingan Terhadap Sistem Peradilan Pidana Anak, Yohanes Ivan ${ }^{6}$ yang mengkaji tentang Eksistensi Hukum Pidana Adat Dalam Menangani Delik Adat Pada Masyarakat Hukum Adat Dayak Pangko dan Di Desa Lape Kecamatan Sanggau Kapuas Kabupaten Sanggau Provinsi Kalimantan Barat, Raonigel Talu Maraga $^{7}$, dengan judul Penyelesaian Sengketa Kepemilikan Tanah Di Lingkungan Masyarakat Adat Dayak Kanayatn, Kecamatan Menyuke, Kabupaten Landak, Provinsi Kalimantan Barat.

Ketiga kajian di atas lebih fokus kepada penyelesaian perkara melalui hukum adat dayak dan tidak membahas secara teknis tentang pelaksanaan eksekusi dari putusan adat dayak yang diputus oleh lembaga peradilan adat, dalam hal ini adalah Kedamangan. Sehingga kajian ini mengandung unsur kebaruan sebagaimana pendapat Soejono Soekanto yang menyatakan suatu kajian atau penelitian yang dilakukan harus dapat mengisi kekosongan yang ada. ${ }^{8}$ Permasalahan yang ada ditengah masyarakat harus dilakukan antisipasi sejak sekarang, jangan menunggu terjadi suatu permasalahan baru aturan tersebut dibuat, sebagaimana hukum bisa dijadikan alat kontrol dan perubahan sosial agar orang jangan sampai melakukan suatu kejahatan atau agar orang dapat mematuhi

\footnotetext{
${ }^{5}$ Sri Ismawati. Mekanisme Penyelesaian Perkara Anak Yang Berhadapan Dengan Hukum Pada Masyarakat Dayak Kanayatn (Kajian Perbandingan Terhadap Sistem Peradilan Pidana Anak)," Jurnal Dinamika Hukum 13, No. 2. 2013.

${ }^{6}$ Yohanes Ivan. "Eksistensi Hukum Pidana Adat Dalam Menangani Delik Adat Pada Masyarakat Hukum Adat Dayak Pangkodan Di Desa Lape Kecamatan Sanggau Kapuas Kabupaten Sanggau Provinsi Kalimantan Barat. Yogyakarta: Fakultas Hukum Universitas Atma Jaya, 2015.

7 Raonigel Talu Maraga, "Penyelesaian Sengketa Kepemilikan Tanah Di Lingkungan Masyarakat Adat Dayak Kanayatn, Kecamatan Menyuke, Kabupaten Landak, Provinsi Kalimantan Barat” Semarang: Program Pascasarjana Universitas Diponegoro, 2007.
}

${ }^{8}$ Soejono Soekanto, Pengantar Penelitian Hukum (Edisi Revisi), Jakarta: UI Press, 2010, hal. 107 
hukum, dimana yang tadinya tidak tertib menjadi tertib. Kekosongan ataupun kekaburan norma hukum yang mengatur masalah pelaksanaan eksekusi putusan adat harus di rumuskan, sehingga kajian pengaturan eksekusi putusan adat dayak ini berguna dan penting untuk dilakukan. Maka penulis memberi judul kajian ini "Pengaturan dan Akibat Hukum Tidak Dilaksanakanya Putusan Peradilan Adat Dayak".

\section{B. Metode Penulisan}

Tulisan ini menggunakan metode penulisan hukum normatif dengan didasarkan pada pengkajian hukum positif. ${ }^{9}$ Pada kajian ini fokus kepada konseptual, doktrinal dan asas hukum serta pendekatan peraturan perundangundangan ${ }^{10}$ untuk mengkaji permasalahan pengaturan eksekusi putusan peradilan adat dayak dan akibat hukum tidak dilaksanakannya putusan peradilan adat dayak. Tipe kajian ini deskriptif analisis ${ }^{11}$ yakni menganalisis bahan hukum primer dan bahan hukum sekunder dihubungkan dengan teori hukum guna menyelesaikan permasalahan. Bahan hukum primer ${ }^{12}$ adalah bahan hukum yang bersifat autoritatif artinya mempunyai otoritas. Bahan hukum primer terdiri dari peraturan perundang-undangan, catatan-catatan resmi atau risalah dalam pembuatan perundang-undangan dan putusan-putusan hakim, sedangkan bahan hukum sekunder adalah semua publikasi tentang hukum yang bukan merupakan dokumen-dokumen resmi. Adapun teknik pengumpulan bahan hukum primer berupa undang-undang ${ }^{13}$, hukum adat dayak perjanjian damai Tumbang Anoi 1894, melalui studi kepustakaan dan sebagian bahan hukum sekunder berupa buku-buku, jurnal dan hasil wawancara dari narasumber, kemudian kedua bahan hukum ini diolah menjadi satu kesatuan yang saling berhubungan dengan permasalahan hukum dihubungkan dengan teori hukum kemanfaatan dan teori sejarah hukum sehingga digunakan untuk menjawab permasalahan hukum yang dikaji guna mendapatkan suatu kesimpulan.

\section{Pembahasan}

\section{Pengaturan Eksekusi Putusan Peradilan Adat Dayak}

Pengaturan eksekusi terhadap putusan peradilan adat dayak di masa lampau bersifat tidak tertulis dan dilakukan berdasarkan kebiasaan dan dipertahankan secara turun temurun oleh masyarakat hukum adat dayak melalui perangkat Kedamangan. Pelaksanaan putusan adat pada masa lampau dilakukan secara sukarela tanpa unsur paksaan, karena sifat religius magis dari hukum adat

\footnotetext{
${ }^{9}$ O Dyah and Efendi A'an, Penelitian Hukum (Legal Research), Jakarta: Sinar Grafika. 2014, hal 14

${ }^{10}$ Peter Mahmud Marzuki, Penelitian Hukum: Edisi Revisi. Jakarta: Prenada Media, 2017, hal. 93-96

${ }^{11}$ Zainuddin Ali, Metode Penelitian Hukum. Edisi 1 Cetakan Ketiga. Jakarta: Sinar Grafika, 2011), hal 107

${ }^{12}$ Peter Mahmud Marzuki, Loc. Cit, hal. 141

${ }^{13}$ Zainal Asikin Amiruddin, Pengantar Metode Penelitian Hukum Edisi Revisi, Raja Gravindo Persada, Jakarta, 2016, hal. 171.
} 
dayak dipercaya memberikan suatu kebaikan apabila dipatuhi sedangkan tidak ditaatinya putusan hukum adat dayak akan membawa malapetaka bagi pelaku dan juga bagi kesatuan masyarakat hukum adat dayak.

Pada masa lampau masyarakat suku dayak sudah mengenal dan memiliki suatu lembaga adat yang terbentuk berdasarkan adat istiadat dan keyakinan masyarakat adat dayak itu sendiri. Masyarakat adat dayak sangat taat dan memiliki kesadaran hukum di dalam menjalankan hukum adat dayak, tidak terkecuali putusan Kedamangan, karena masyarakat adat dayak memiliki keyakinan, hukum adat yang mereka jalankan memiliki nilai spiritual atau nilai religius magis dan memiliki pengaruh yang sangat besar di dalam kehidupan masyarakat adat dayak. Hukum adat dayak lahir dari kebiasaan-kebiasaan dari tatanan kehidupan masyarakat adat dayak yang senantiasa dipertahankan secara turun temurun, masyarakat adat dayak percaya bahwa hukum yang mereka jalankan adalah hukum yang lahir dari kehidupan masyarakat adat dayak itu sendiri, sehingga sejalan dengan mazhab sejarah ${ }^{14}$ lahirnya hukum sebagaimana yang disampaikan oleh Carl Von Savigny adalah hukum lahir dari sejarah dan semangat suatu bangsa, menjadi hukum kebiasaan yang berasal dari perasaan dan jiwa dari suatu bangsa. Hukum adat dayak ada yang bersifat tertulis dan ada yang bersifat tidak tertulis, hukum adat yang tidak tertulis termuat di dalam prinsif dasar kehidupan masyarakat adat yang beberapa diantaranya adalah prinsif Belom Bahadat, Prinsif Huma Betang dan prinsif Penyang Hinje Simpei, sedangkan hukum adat dayak yang bersifat tertulis yakni 96 Pasal yang terdapat di dalam ketentuan perjanjian damai Tumbang Anoi 1894. Sanksi hukum adat dayak yang ada terdapat di dalam ketentuan perjanjian damai Tumbang Anoi 1894 adalah Singer ${ }^{15}$ atau denda adat dengan menggunakan istilah Kati Ramu dan melakukan ritual adat tertentu tergantung dari pelanggaran adat yang dilakukan bisa berupa, Singer Tungkun sanksinya pesta perdamaian potong babi (Pasal 1), Singer Tungkun Balang Dosa Palus (Pasal 2), Singer Hatulang Belum (Pasal 3), Singer Hatulang Palekak Sama Handak sanksinya pesta persaudaraan hambai hampahari (Pasal 4), Singer Sahiring (Singer Pembunuhan) sanksinya Pesta Adat, Saki palas, tawur behas hasumpah hajanji terai habunu dan lain sebagainya.

Hukum menurut masyarakat adat dayak merupakan kesatuan peraturan yang berisikan nilai spiritual dan moral yang membawa masyarakat adat dayak ke dalam tatanan kehidupan yang lebih baik dan tertib sebagaimana esensi moral adalah nilai perilaku baik dan buruk. ${ }^{16}$ Tujuan dari hukum adat dayak adalah tercapainya kedamaian dan kesejahteraan di dalam lingkup kesatuan masyarakat

\footnotetext{
${ }^{14}$ Muhammad Erwin, Filsafat Hukum Refleksi Kritis Terhadap Hukum, Jakarta: Rawali Press, 2012, hal. 189191

${ }^{15}$ Bidang Hukum Dan Advokasi Dewan Adat Dayak Kota Palangka Raya, Standar Operasional Prosedur Penyelesaian Sengketa Adat Dayak Di Kota Palangka Raya (Palangka Raya: Dewan Adat Dayak Kota Palangka Raya, 2018, hal 44-55

${ }^{16}$ Salman Luthan, Dialektika Hukum Dan Moral Dalam Perspektif Filsafat Hukum, Ius Quia Iustum Law Journal 19, no. 4, 2012, hal. 506-523.
} 
hukum adat dayak. Artinya hukum menurut masyarakat adat dayak adalah hukum yang memiliki manfaat kepada orang banyak khususnya masyarakat adat dayak hal ini sejalan sebagaimana teori kemanfaatan hukum (Utilitarianisme) Jeremy Bentham $^{17}$ yang menyatakan hukum harus memberikan manfaat kebaikan, kebahagiaan dan mencegah kejahatan. Konsep pengaturan hukum untuk masa yang akan datang, yang salah satunya sanksi bagi setiap orang yang tidak mematuhi putusan adat dayak yang dikeluarkan oleh Kedamangan merupakan konsep hukum yang memiliki kemanfaatan bagi masyarakat adat dayak agar siapa saja yang diputus menggunakan hukum adat dayak agar menghormati hukum adat dayak agar tercapainya suatu kebahagian sebagaimana mashab utilitarianisme. Ketertiban hukum dapat terwujud dan memiliki manfaat kepada masyarakat adat dayak, yang salah satunya apabila pelaku tidak mematuhi putusan adat maka pelaku wajib melakukan ritual adat untuk membersihkan pelanggaran yang telah diperbuat, agar masyarakat adat dayak dapat terhindar dari bencana atau malapetaka yang diakibatkan pelanggaran hukum adat oleh pelaku. Masyarakat adat dayak mempercayai bahwa pelanggaran terhadap hukum adat akan berdampak luas kepada masyarakat adat dayak itu sendiri. Konsep hukum berikutnya adalah memberikan keleluasaan kepada Damang untuk melakukan penafsiran terhadap prinsif dasar hukum adat dayak, hal ini untuk mengisi kekosongan hukum dan ketidakjelasan ketentuan hukum adat dayak yang dapat berdampak pada tidak terlaksananya penegakan hukum adat oleh Kedamangan.

Kewenangan Kedamangan dalam menjalankan peradilan adat dayak tidak bertentangan dengan kewenangan Mahkamah Agung dalam menjalankan seluruh peradilan yang ada di Indonesia, walaupun pada Pasal 18 Undang-Undang 48 Tahun 2009 tentang Kekuasaan Kehakiman menyatakan kekuasaan kehakiman dilakukan oleh sebuah Mahkamah Agung dan badan peradilan yang berada di bawahnya dalam lingkungan peradilan umum, lingkungan peradilan agama, lingkungan peradilan militer, lingkungan peradilan tata usaha negara, dan oleh sebuah Mahkamah Konstitusi. Kedamangan mengadili perkara apabila perbuatan seseorang tersebut melanggar hukum adat dayak. Penerapan dan pelaksanaan peradilan adat dayak yang dijalankan oleh Kedamangan tetap memperhatikan ketentuan peraturan perundang-undangan yang berlaku, sehingga dengan kata lain pelaksanaan peradilan adat dayak tidak bertentangan dengan hukum positif di Indonesia. Keberadaan peradilan adat dari sejarah dan eksistensinya ${ }^{18}$ diatur pada ketentuan Pasal 1, Pasal 5 ayat (3) sub b Undang-Undang Darurat Nomor 1 Tahun 1951 tentang tindakan-tindakan sementara untuk menyelenggarakan kesatuan susunan kekuasaan dan acara pengadilan-pengadilan sipil, Pasal 5 ayat (1), dan Pasal 50 ayat (1) Undang-Undang Nomor 48 Tahun 2009 tentang Kekuasaan Kehakiman yang berbunyi Putusan pengadilan selain harus memuat alasan dan dasar putusan, juga memuat pasal tertentu dari peraturan perundang-undangan

${ }^{17}$ Darji Darmodiharjo, Dan Shidarta, Pokok-Pokok Filsafat Hukum, Apa Dan Bagaimana Filsafat Hukum Indonesia, vol. Revisi, Jakarta: Gramedia Pustaka Utama. 2014, hal 116-117

${ }^{18}$ Lilik Mulyadi, Eksistensi Hukum Pidana Adat Di Indonesia: Pengkajian Asas, Norma, Teori, Praktik Dan Prosedurnya, Jurnal Hukum Dan Peradilan 2, no. 2. 2013, hal. 245. 
yang bersangkutan atau sumber hukum tak tertulis yang dijadikan dasar untuk mengadili. Kemudian secara parsial dalam daerah tertentu seperti Aceh Nangroe Darussalam diatur dalam Undan-Undang Nomor 44 Tahun 1999 tentang Penyelenggaraan Keistimewaan Propinsi Daerah Istimewa Aceh, Undang-Undang Nomor 11 Tahun 2006 tentang Tentang Pemerintahan Aceh, berikutnya diimplementasikan dalam bentuk Qanun baik tingkat Propinsi dan Kabupaten seperti Qanun Aceh Nomor 10 Tahun 2008 tentang Lembaga Adat, Qanun Kabupaten Aceh Tengah Nomor 10 Tahun 2002 tentang Hukum Adat Gayo. Berikutnya di Bali diatur dan diimplementasikan dalam bentuk Awig-Awig Desa Adat (Pakraman) serta dari perspektif ius constituendum diatur dalam ketentuan Pasal 2 ayat (1), (2) Rancangan Kitab Undan-Undang Hukum Pidana Tahun 2012. Kemudian tataran asas diatur Kitab Ciwasasana atau Kitab Purwadhigama, Kitab Gajahmada, Kitab Simbur Cahaya, Kitab Kuntara Raja Niti, Kitab Lontara ,ade dan awig-awig. Ketentuan hukum adat yang ada di Bali ataupun penerapan hukum Islam yang dikenal dengan Qanun di Aceh memiliki kesamaan seperti yang ada di Kalimantan secara umum dan Kalimantan Tengah secara khusus yakni penerapan 96 Pasal perjanjian damai Tumbang Anoi 1894.

Berdasarkan sejarahnya pada masa awal, kehidupan masyarakat adat dayak hidup berkelompok yang di dalamnya dipimpin oleh kepala adat yang mengurus ke dalam maupun ke luar dalam kaitan tatanan kehidupan. Sedangkan pada masa pertengahan, kelompok masyarakat adat semakin besar maka sistem kepemimpinan masyarakat adat dayak terbagi menjadi empat meliputi: ${ }^{19}$

1. Tamanggung atau Dambung yang kedudukannya sama dengan raja yang bertugas melindungi, mensejahterakan dan memakmurkan masyarakat.

2. Pangkalima, bertanggungjawab dalam bidang pertahanan dan keamanan.

3. Patih memiliki tanggungjawab dalam bidang pemerintahan dan kesejahteraan masyarakat.

4. Damang, memiliki tanggungjawab dalam bidang pengawsan, penuntutan, dan peradilan.

Pelaksanaan eksekusi putusan peradilan adat dayak pada masa lampau dilaksanakan sepenuhnya oleh Damang, karena Damang memiliki tanggungjawab dalam bidang peradilan adat.

Pada masa sekarang pengaturan eksekusi putusan peradilan adat dayak terdapat pada Peraturan Daerah Provinsi Kalimantan Tengah Nomor 16 Tahun 2008 tentang Kelembagaan Adat Dayak Di Kalimantan Tengah. Dasar pengaturan eksekusi putusan peradilan adat dayak sebagai implementasi dari pelaksanaan dan penegakan hukum adat dayak baik yang bersifat tidak tertulis maupun hukum adat dayak yang bersifat tertulis yakni Perjanjian Damai Tumbang Anoi Tahun 1894.

${ }^{19}$ Y. Nathan Ilon, Loc. Cit. 
Isi dari Perjnjian Damai Tumbang Anoi $1894^{20}$ tidak hanya menghentikan peperangan, Perjanjian Tumbang Anoi merupakan perjanjian yang mengusung semangat perdamaian dan persatuan, karena pokok perjanjiannya adalah menghentikan Наbunu (saling membunuh), Hakayau (saling potong kepala), dan Hajipen (saling memperbudak) antar sesama orang dayak, tetapi juga berisikan perumusan aturan kehidupan dan pemberlakuan hukum adat dayak bagi seluruh suku dayak yakni adanya 96 Pasal, terkait perintah ataupun larangan yang harus dipatuhi oleh seluruh suku dayak yang menjadi dasar atau pondasi kehidupan guna menjaga perdamaian agar terciptanya tatanan kehidupan yang baik dan damai.

Eksekusi terhadap putusan adat dayak, pengaturannya tidak ditemukan di dalam perjanjian Tumbang Anoi, karena perjanjian Tumbang Anoi lebih mengatur kepada hukum materil yang berisikan larangan-larangan, dan sanksi-sanksi, atau hukuman terhadap pelaku yang melanggarnya, sedangkan proses eksekusi terkait putusan peradilan adat lebih kepada hukum formil atau hukum acara terhadap penegakan hukum adat dayak, akan tetapi pada Pasal 96 Perjanjian Tumbang Anoi 1894 dapat memungkinkan adanya sanksi bagi pihak yang melanggar tatanan hidup masyarakat yang sering di sebut dengan prinsif "Belom Bahadat". Berikut isi dari Pasal 96 Perjanjian Damai Tumbang Anoi 1894 "Kasukup Singer Belom Bahadat ${ }^{21}$ (Kelengkapan denda adat hidup kesopanan atau beretika atau bermoral yang tinggi), Belom bahadat merupakan prinsip hidup masyarakat adat dayak ngaju yang memiliki arti hidup baik sesuai dengan aturan atau kebenaran. Pihak yang tidak menjalankan putusan adat dayak dianggap tidak Bahadat, dan dapat dikategorikan sebagai pelecehan terhadap hukum adat dayak dan pelecehan terhadap peradilan adat dayak, yang dalam hal ini dijalankan oleh Kedamangan. Belom Bahadat sebagai prinsif hukum adat dayak dikarenakan Belom Bahadat merupakan falsafah hidup yang baik dan benar berdasarkan aturan dan tatanan kehidupan masyarakat adat dayak yang selama ini berlaku dan dipertahankan secara turun temurun. Belom bahadat memiliki makna tiga citra sikap ${ }^{22}$ yakni pertama sikap meyembah kepada Tuhan Yang Maha Esa atau damai dengan Tuhan sang pencipta alam semesta, kedua sikap hormat sesama manusia atau damai dengan sesama manusia dan ketiga sikap santun yang di implementasikan dengan menjunjung tinggi norma-norma dan taat hukum untuk ketentraman dan ketertiban. Segala perbuatan yang tidak sesuai dengan ketiga makna yang terkandung tersebut dianggap bertentangan dengan hukum adat dayak.

Peraturan teknis terkait eksekusi putusan peradilan adat dayak secara tertulis tidak diatur, akan tetapi dapat diterjemahkan ke dalam Pasal 96 Perjanjian Tumbang Anoi 1894 dan dilanjutkan dengan pertemuan Damang di seluruh

\footnotetext{
${ }^{20}$ Citranu, "Perjanjian Tumbang Anoi 1894 Sebagai Sumber Hukum Pidana Adat Dayak Ngaju," Tampung Penyang Vol 17 No (2019): https://doi.org/https://doi.org/10.33363/tampung-penyang.v17i01.395. hal. 9

${ }^{21}$ Bidang Hukum Dan Advokasi Dewan Adat Dayak Kota Palangka Raya, Loc. Cit, hal. 106

${ }^{22}$ Citranu. Loc. Cit, hal. 9
} 
Kapuas Pada Tanggal 3 September 1928 yang memungkinkan apabila adanya keberatan atau merasa tidak puas terkait keputusan adat yang diadili oleh lembaga adat dalam hal ini kedamangan, maka dapat membawa surat keterangan dari Damang untuk diadili di peradilan umum. Hasil pertemuan tanggal 3 September 1928 selanjutnya dikukuhkan pada tanggal 2 april tahun 1953 di Kuala Kapuas yang diadakan rapat bersama Damang Kepala Adat se Kabupaten Kapuas. ${ }^{23}$

Putusan peradilan adat dayak disini dikategorikan 2 (dua) macam putusan yakni yang pertama putusan dalam ranah hukum perdata, putusan yang bersifat mendamaikan yang berisi kesepakatan para pihak untuk berdamai dan putusan dalam lingkup hukum pidana adat yang bersifat menghukum sebagaimana pelanggaran terhadap pasal-pasal di dalam Perjanjian Damai Tumbang Anoi 1894 seperti pencurian, pembunuhan, penganiayaan, penghinaan, pengrusakan, kesusilaan dan tindak pidana adat lainnya.

Kelemahan dari putusan adat dayak yang dikeluarkan oleh Kedamangan yakni putusan peradilan adat dayak tidak memiliki kekuatan eksekutorial atau kekuatan memaksa untuk menjalankan putusan peradilan adat dayak sebagaimana hukum nasional yang memiliki panitera dan juru sita dipimpin oleh ketua pengadilan di dalam hukum perdata sebagaimana Pasal 54 Undang-Undang Nomor 48 Tahun 2009 Tentang Kekuasaan Kehakiman, yang berbunyi: (1) Pelaksanaan putusan pengadilan dalam perkara pidana dilakukan oleh jaksa. (2) Pelaksanaan putusan pengadilan dalam perkara perdata dilakukan oleh panitera dan juru sita dipimpin oleh ketua pengadilan. (3) Putusan pengadilan dilaksanakan dengan memperhatikan nilai kemanusiaan dan keadilan. Pelaksanaan putusan ini juga ditentukan dalam HIR Pasal 195-224 dan Rbg Pasal 206-240 Rbg dan 258 $\mathrm{Rbg})^{24}$. Sedangkan pelaksanaan eksekusi putusan perkara pidana nasional dilakukan oleh jaksa sebagaimana ketentuan Pasal 270 KUHAP. Hukum acara yang mengatur pelaksanaan putusan peradilan adat dayak yang dilaksanakan Kedamangan tidak ada, hal ini yang membuat putusan peradilan adat dayak tidak memiliki kekuatan eksekutorial.

Menurut Sudikno pelaksanaan eksekusi putusan perdata meliputi membayar sejumlah uang (Pasal $196 \mathrm{HIR} / 208 \mathrm{RbG}$ ), melaksanakan suatu perbuatan (Pasal $225 \mathrm{HIR} / 259 \mathrm{RbG}$ ), eksukusi riil (Pasal $1033 \mathrm{Rv}$ ), parate eksekusi (1155, 1175 Ayat (2) BW), Serta memiliki asas putusan telah memiliki kekuatan hukum tetap, Putusan tidak dijalankan secara sukarela, Putusan harus

\footnotetext{
${ }^{23}$ Biro Pemerintahan Desa Setwilda Tingkat I Kalimantan Tengah, Lembaga Kedamangan Dan Hukum Adat Dayak Ngaju Di Provinsi Kalimantan Tengah (Palangka Raya: Panitia Seminar Dan Lokakarya Kebudayaan Dayak dan Hukum Adat Di Kalimantan Tengah, 1996)., hal. 21-22

${ }^{24}$ Sri Hartini, Setiati Widihastuti, and Iffah Nurhayati, "Eksekusi Putusan Hakim Dalam Sengketa Perdata Di Pengadilan Negeri Sleman," Jurnal Civics: Media Kajian Kewarganegaraan, 2017,https://doi.org/10.21831/civics.v14i2.16852, hal. 129
} 
bersifat penghukuman (condemnatoir), Eksekusi atas perintah dan dibawah pimpinan Ketua Pengadilan Negeri. ${ }^{25}$

Menurut Peraturan Daerah Provinsi Kalimantan Tengah Nomor 16 Tahun 2008 tentang Kelembagaan Adat Dayak Di Kalimantan Tengah, Pasal 3 ayat 1 Kedamangan adalah lembaga adat dan merupakan unsur utama di dalam sistem peradilan adat dayak di dalam menegakan hukum adat dayak yang ada sesuai dengan wilayah hukum adatnya, Kedamangan beserta perangkatnya terdiri dari Damang, Mantir adat atau Let adat yang memiliki tugas dan fungsinya masingmasing di dalam lembaga adat dayak. Pasal 1 Ayat 25 Kedamangan adalah suatu Lembaga Adat Dayak yang memiliki wiiayah adat, kesatuan masyarakat adat dan hukum adat dalam wilayah Provinsi Kalimantan Tengah yang terdiri dari himpunan beberapa desa kelurahan / kecamatan /Kabupaten dan tidak dapat dipisah-pisahkan. Pasal 1 ayat 24 Damang Kepala Adat adalah pimpinan adat dan Ketua Kerapatan Mantir Perdamaian Adat tingkat kecamatan yang berwenang menegakkan hukum adat Dayak dalam suatu wilayah adat yang pengangkatannya berdasarkan hasil pemilihan oleh para kepala desa/kelurahan, para ketua Badan Permusyawaratan Desa. Lembaga Kemasyarakatan Kelurahan para Mantir Adat Kecamatan. Para Ketua Kerapatan Mantir Adat Perdamaian desa/kelurahan yang termasuk dalam wilayah Kedamangan tersebut. Ayat 26 Kerapatan Mantir Adat atau Kerapatan Let Adat adalah perangkat adat pembantu Damang atau gelar bagi anggota Kerapatan Mantir Perdamaian Adat di tingkat kecamatan dan anggota Kerapatan Mantir Perdamaian Adat tingkat desa/kelurahan, berfungsi sebagai peradilan adat yang berwenang membantu Damang Kepala Adat dalam menegakkan hukum adat Dayak di wilayahnya.

Peran Damang sangat penting di dalam pelaksanaan eksekusi putusan peradilan adat dayak, sebagaimana Pasal 8 huruf a Damang memiliki tugas menegakan hukum adat dan menjaga wibawa lembaga adat Kedamangan dan huruf c Damang bertugas menyelesaikan perselisihan dan atau pelanggaran adat, dimungkinkan juga masalah-masalah yang termasuk dalam perkara pidana, baik dalam pemeriksaan pertama maupun dalam sidang penyelesaian terakhir sebagaimana lazimnya menurut adat yang berlaku. Damang beserta perangkatnya selain memutus perkara dalam lingkup adat juga memiliki pengaruh besar untuk menjalankan proses eksekusi terhadap keputusan adat yang telah dikeluarkan di dalam penyelesaian sengketa adat. Eksekusi terhadap putusan peradilan adat dayak merupakan wujud kehormatan dan wibawa lembaga adat yang dalam hal ini kedamangan. Putusan peradilan adat dayak bersifat final dan mengikat terhadap para pihak yang bersengketa atau pihak yang diadili berdasarkan hukum adat dayak, sehingga putusan peradilan adat dayak mutlak dan wajib untuk dilaksanakan. Damang selain sebagai pemeriksa dan pengambil keputusan terhadap perkara-perkara adat, juga memiliki fungsi sebagai mediator atau penengah untuk mendamaikan para pihak yang bersengketa. Damang memiliki

${ }^{25}$ Depri Liber Sonata, "Permasalahan Pelaksanaan Lelang Eksekusi Putusan Pengadilan Dalam Perkara Perdata Dalam Praktik," Fiat Justisia 6, no. 2 (2015)., hal. 4 
fungsi sebagaimana Pasal 9 (1) a. mengurus, melestarikan, memberdayakan dan mengembangkan adat istiadat, kebiasaan-kebiasaan, hukum adat dan lembaga kedamangan yang dipimpinnya b. menegakkan hukum adat dengan menangani kasus dan atau sengketa berdasarkan hukum adat dan merupakan peradilan adat tingkat terakhir; dan c. sebagai penengah dan pendamai atas sengketa yang timbul dalam masyarakat berdasarkan hukum adat.

Damang memiliki hak, wewenang dan kewajiban berdasarkan Pasal 10 Peraturan Daerah Provinsi Kalimantan Tengah Nomor 16 Tahun 2008 tentang Kelembagaan Adat Dayak Di Kalimantan Tengah (1) Damang Kepala Adat mempunyai hak dan wewenang sebagai berikut: a. menganugerahkan gelar adat kepada seseorang atas prestasi dan jasa-jasanya yang telah berbuat untuk mengangkat harkat dan martabat Masyarakat Adat Dayak; b. mengelola hak-hak adat dan/atau harta kekayaan Kedamangan untuk meningkatkan kemajuan dan taraf hidup masyarakat ke arah yang lebih layak dan lebih baik, c. menyelesaikan perselisihan yang menyangkut adat istiadat, kebiasaan-kebiasaan dan hak-hak adat masyarakat adat Dayak, d. menetapkan Peraturan Damang, membuat surat keputusan, mengesahkan surat pernyataan, membuat surat keterangan tanah adat dan atau hak-hak adat di atas tanah; dan e. melaksanakan perkawinan secara adat, menerbitkan surat keterangan perkawinan secara adat, mengesahkan surat perjanjian perkawinan secara adat, mengeluarkan surat keterangan perceraian secara adat dan surat-surat lainnya yang berkaitan dengan hukum adat sepanjang diminta oleh pihak-pihak berkepentingan. (2) Damang Kepala Adat berkewajiban untuk melakukan hal-hal sebagai berikut: a. membantu kelancaran penyelenggaraan pemerintahan, pelaksanaan pembangunan dan pembinaan kemasyarakatan terutama dalam pemanfaatan hak-hak adat dan harta kekayaan kedamangan agar tetap memperhatikan kepentingan masyarakat adat setempat, $b$. ikut memelihara stabilitas daerah dan nasional yang sehat dan dinamis yang dapat memberikan peluang yang luas kepada aparat pemerintah terutama Pemerintah kecamatan dan desa/kelurahan dalam melaksanakan tugas-tugas penyelenggaraan pemerintahan yang bersih dan berwibawa, pelaksanaan pembangunan yang lebih berkualitas dan pembinaan masyarakat yang adil dan demokratis, c. ikut menciptakan suasana yang tetap dapat menjamin terpeliharanya semboyan Bineka Tunggal Ika dalam masyarakat di wilayahnya; dan $d$. mengawasi dan mengantisipasi budaya luar yang dipandang negatif dan dapat mengancam keberadaan adat dan budaya Dayak. e. selalu mengingatkan dan mendorong agar seluruh warga masyarakat adat Dayak ikut bertanggung jawab dalam menjaga, melestarikan, mengembangkan dan membudayakan falsafah hidup "Budaya Huma Betang atau Belom Bahadat".

Damang memiliki kewenangan untuk menjalankan putusan adat dayak bisa di interpretasikan berdasarkan pasal 10 huruf c, Damang menyelesaikan perselisihan atau perkara yang menyangkut adat istiadat dan Damang dapat membuat peraturan untuk memberikan sanksi kepada setiap orang yang menolak putusan adat dayak yang dikeluarkan oleh Kedamangan sebagaimana pasal 10 huruf d. Kedudukan Damang selaku penegak hukum adat memiliki peran yang sangat strategis untuk mengisi kekosongan dan kekaburan hukum adat dayak. 
Damang harus memiliki integritas dan profesionalitas serta kemampuan untuk membaca situasi perkembangan yang ada di dalam masyarakat adat dayak agar pertimbangan dan putusan adat yang Damang keluarkan berkeadilan danmemenuhi harapan masyarakat adat dayak.

Peradilan adat dayak yang sudah mencapai hasil dan melahirkan suatu putusan adat akan memiliki kekuatan hukum mengikat dan bersifat akhir, dalam hal ini Damang di dalam proses pelaksanaan eksekusi putusan adat dayak dibantu oleh Barisan Pertahanan Adat Dayak (Batamad) yang memiliki tugas dan fungsi sebagaimana Pasal 34 (1) Peraturan Daerah Nomor 16 Tahun 2008 tentang Kelembagaan Adat Dayak Di Kalimantan Tengah, yakni untuk menjamin agar dipatuhinya sanksi Adat yang telah ditetapkan, maka Damang Kepala Adat bersama Kerapatan Mantir/Let Perdamaian Adat didukung oleh Dewan Adat Dayak melalui Barisan Pertahanan Masyarakat Adat Dayak. Pada pelaksanaannya Batamad yang memiliki tugas untuk membantu Damang dalam hal menjamin sanksi adat dapat dipatuhi, tidak memiliki kewenangan untuk melakukan paksaan terhadap pelaksanaan putusan peradilan adat dayak. Batamad tidak boleh melakukan kekerasan terhadap pihak yang tidak bersedia menjalankan putusan apalagi melakukan intimidasi, karena pada dasarnya penerapan hukum adat dayak juga tidak boleh bertentangan dengan hukum nasional. Semua tindakan yang dilakukan oleh perangkat Kedamangan di dalam penegakan hukum adat dayak tidak boleh dilakukan secara melawan hukum.

Pengaturan hukum teknis pelaksanaan eksekusi putusan peradilan adat dayak untuk masa yang akan datang harus dibuat di dalam ketentuan hukum adat dayak yang bersifat tertulis dan lebih jelas agar putusan peradilan adat dayak dapat dilaksanakan dan memiliki kekuatan eksekutorial sebagaimana hukum nasional sehingga pelaksanaan eksekusi putusan peradilan adat dayak juga memiliki kepastian hukum, misalnya siapa pihak yang memiliki kewenangan untuk melaksanakan eksekusi putusan peradilan adat dayak, selanjutnya terhadap pihak yang tidak membayar singer atau denda, maka terhadap harta yang bersangkutan akan disita dan dilelang untuk melaksanakan putusan atau ritual adat atau bagi pihak tidak melaksanakan putusan adat bisa diajukan dan dilaporkan pidana nasional karena tidak menjalankan putusan adat dan telah melecehkan peradilan adat dayak.

\section{Akibat hukum tidak dilaksanakannya putusan peradilan adat dayak}

Akibat hukum tidak dilaksanakannya putusan peradilan adat dayak yakni diberikan sanksi adat lebih berat lagi, bisa berupa Singer atau denda dengan jumlah besar, pengusiran dari kelompok masyarakat adat dayak dan dilaporkan ke Polisi karena telah melecehkan peradilan adat dayak dengan tidak mematuhi putusan adat yang dikeluarkan oleh kedamangan atau dapat mengajukan gugatan perdata menggunakan putusan peradilan adat sebagai bukti dan dasar gugatan. Selain dari akibat secara hukum karena tidak dilaksanakannya putusan peradilan adat dayak tersebut memiliki akibat secara spiritual yakni adanya goncangan dan ketidakseimbangan antara alam manusia dengan alam gaib karena pelanggaran 
adat yang sudah terjadi, ${ }^{26}$ sedangkan peradilan adat yang tujuannya untuk sarana memberikan dan mengembalikan keseimbangan melalui putusan adat berupa sanksi ritual adat tidak dilaksanakan, maka masyarakat setempat dipercaya akan mendapatkan suatu hal buruk, hal inilah kenapa putusan peradilan adat dayak wajib dilaksanakan apalagi sanksi tersebut untuk melaksanakan ritual adat, sebagaimana sanksi sendiri memiliki pengertian sebagai bentuk kaidah hukum yang melindungi dan menjamin kepentingan individu dan sosial dengan memaksakan tujuan keadilan yang dapat dipaksakan melalui sanksi hukum yang dapat dilakukan oleh petugas-petugas yang ditetapkan untuk itu, penerapan sanksi adalah sebagai salah satu cara untuk memberikan keseimbangan terjadinya permasalahan dalam masyarakat. ${ }^{27}$ Pendapat Damang Jekan Raya dan Damang Pahandut terhadap tidak dipatuhinya putusan peradilan adat dayak sebagai berikut:

Hasil wawancara penulis pada tanggal 22 Oktober 2019 dengan bapak Drs. Kardinal Tarung selaku Damang Jekan Raya akan memberikan sanksi tambahan terhadap pihak yang tidak mematuhi putusan peradilan adat dayak, karena pihak yang dihukum tidak melaksanakan putusan adat maka dapat dikatakan pihak tersebut telah melecehkan hukum adat dan peradilan adat serta dianggap tidak bahadat. Dasar untuk memberikan sanksi adat yakni surat keputusan Damang Nomor: 011/ DKA-KJR///2019 tentang Pelaksanaan Putusan Damang di Lingkungan Kedamangan Kecamatan Jekan Raya. Kehidupan masyarakat adat dayak erat kaitannya dengan prinsif "belom bahadat" yang mengandung tiga citra sikap yakni pertama sikap meyembah kepada Tuhan Yang Maha Esa atau Damai dengan Tuhan sang pencipta alam semesta, kedua sikap hormat sesama manusia atau damai dengan sesama manusia dan ketiga sikap santun yang diimplementasikan dengan menjunjung tinggi norma-norma dan taat hukum untuk ketentraman dan ketertiban. Sanksi tambahan yang lebih berat atas perbuatan yang tidak mengindahkan putusan adat tersebut bisa berupa, singer atau denda dan pengusiran dari kelompok masyarakat adat tersebut atau pengucilan dari masyarakat adat, sanksi dengan cara melakukan ritual sumpah atau pemberian kutuk terhadap pihak yang telah melanggar hukum adat dan tidak mematuhi putusan peradilan hukum adat (ritual dilakukan oleh rohaniawan/basir/pisor dan hasil ritual ini biasanya apabila terbukti maka bisa menyebabkan hal yang tidak baik sampai mengakibatkan kematian), atau damang dapat merekomendasikan agar perkara yang dihadapi atau dijalani diselesaikan menurut hukum nasional dengan cara menyerahkan pihak yang telah diadili secara hukum adat tersebut kepada aparat penegak hukum yakni kepolisian, kejaksaan ataupun pengadilan. Hal ini berkesesuaian dengan hasil rapat Damang di Kapuas pada tahun 1928 dan tahun 1953, yang memungkinkan perkara adat untuk dilimpahkan ke hukum nasional. Putusan adat dapat dijadikan sebagai bukti ataupun pertimbangan hakim didalam memutus perkara yang bersangkutan dengan cara mempelajari dan

\footnotetext{
${ }^{26}$ Yohanes Ivan. Loc. Cit, hal.2

${ }^{27}$ I Made Kastama, Hukum Adat Dayak: Bentuk, Penerapan Dan Sanksi Singer Di Desa Pendreh Kecamatan Teweh Tengah Kabupaten Barito Utara, Belom Bahadat 8, no. 2 2018, hal. 5-7
} 
menelaah pertimbangan putusan peradilan adat dayak yang dikeluarkan oleh pihak Kedamangan. ${ }^{28}$

Menurut Damang Pahandut Marcos Sabastian Tuwan, S.E, pada wawancara tanggal 24 Oktober 2019, Kedamangan Pahandut akan menerapkan sanksi adat terhadap pihak yang tidak melaksanakan putusan peradilan adat dayak yakni dihukum lebih berat atau dikucilkan dari masyarakat adat diwilayah kedamangan pahandut, kepada pihak yang tidak menjalankan putusan peradilan adat dayak ini juga dapat dilimpahkan ke ranah hukum nasional apabila hal itu menyangkut pidana maka akan diserahkan kepada pihak kepolisian sedangkan apabila berhubungan dengan perkara perdata dapat diajukan ke pengadilan negeri dengan cara pihak berperkara mengajukan gugatan karena tidak menjalankan putusan adat baik itu gugatan perbuatan melawan hukum apabila isi putusan bersifat penghukuman dan dianggap melecehkan hukum adat dan peradilan adat dayak serta dapat mengajukan gugatan wanprestasi apabila putusan adat tersebut bentuknya berupa kesepakatan. Materi pokok gugatan bisa terkait tidak dilaksanakannya putusan peradilan adat ataupun mengenai materi awal sebelum diputusnya perkara di peradilan adat, tergantung penilaian majelis hakim yang memeriksa perkara.

Terhadap putusan adat yang tidak dilaksanakan dan kemudian dilakukan gugatan ke pengadilan ataupun dilaporkan ke Polisi maka sanksi yang tidak bisa tergantikan adalah pihak yang dihukum tetap dipaksa atau dituntut untuk melaksanakan ritual adat dayak untuk mengembalikan keseimbangan yang telah rusak guna terciptanya kedamaian di masyarakat adat dayak. Ritual ini dipercaya sebagai bentuk rehabilitasi antara manusia dengan manusia, manusia dengan alam dan manusia dengan Tuhan. Kehidupan masyarakat adat dayak bersifat religious magis dan tidak memisahkan antara kehidupan nyata dan gaib. ${ }^{29}$

Hukum adat dayak yang ada di Kalimantan Tengah memiliki banyak ragamnya tergantung dari sub suku dayak yang menghuni daerah aliran sungai yang ada di kalimantan tengah, hukum adat dayak yang berlaku memiliki karakteristik masing-masing tergantung wilayah kedamangannya, memiliki tata cara atau aturan hukum adat yang berbeda-beda. Apalagi hukum adat dayak bersifat tidak tertulis dan hanya diketahui oleh para tua-tua kampung atau tokoh adat seperti damang, mantir atau penghulu adat, walaupun tidak tertulis hukum adat dayak tercermin didalam kehidupan masyarakat adat dayak itu sendiri. Keberagaman hukum adat dayak ini sesuai dengan teori yang menyatakan struktur persekutuan hukum adat di seluruh nusantara terjadi dengan dipengaruhi oleh dua faktor yakni territorial berdasarkan lingkungan daerah dan genealogis berdasarkan pertalian keturunan. ${ }^{30}$ Penegakan hukum adat dayak dan penerapan

\footnotetext{
28 Trisno Raharjo, Mediasi Pidana Dalam Ketentuan Hukum Pidana Adat, Ius Quia Iustum Law Journal 17, no. 3. 2010, hal. 492-519.

${ }^{29}$ Sri Ismawati, Loc. Cit. hal. 197-209.

${ }^{30}$ Nikolas Simanjuntak, Penguatan Lembaga Adat Sebagai Alternatif Penyelesaian Sengketa, Negara Hukum: Membangun Hukum Untuk Keadilan Dan Kesejahteraan 4, no. 1. 2016, hal. 35-66.
} 
sanksi serta tata cara penyelesaian sengketa dilakukan berdasarkan wilayah kedamangan dan tidak dapat disamakan. Hal ini yang membuat lahirnya Pasal 33 Peraturan Daerah Provinsi Kalimantan Tengah Nomor 16 Tahun 2008 tentang Kelembagaan Adat Dayak Di Kalimantan Tengah, Pasal 33 mengatur Tata cara penyelesaian sengketa dan tata cara menjatuhkan sanksi adat oleh Damang Kepala Adat melalui Kerapatan Mantir/Let Perdamaian Adat, dilakukan sesuai dengan hukum adat dayak yang berlaku di wilayah Kedamangan masing-masing. Perbedaan hukum adat ini juga berpengaruh terhadap sanksi yang diterapkan terhadap pihak yang tidak melaksanakan putusan peradilan adat dayak, sanksi adat yang diterima akan berbeda-beda tergantung berat ringan sanksi adat yang di tuangkan didalam putusan adat serta dihubungkan dengan hukum adat yang ada diwilayah Kedamangan dimana perkara adat atau pelanggaran adat tersebut dilakukan atau diputus, sesuai dengan isi penjelasan Pasal 33 hakikatnya Damang memiliki kemampuan untuk menetapkan tata cara penjatuhan sanksi adat akan tetapi tetap menyesuaikan dengan perkembangan zaman, baik dari segi sosial maupun dari segi aturan hukum yang berlaku di Indonesia, karena diakuinya keberadaan hukum adat dan berlakunya hukum adat tidak boleh bertentangan dengan hukum nasional yakni Konstitusi UUD RI 1945 dan Pancasila. Hukum yang dijatuhkan oleh Damang tidak semata-mata menghukum dengan memberikan Singer atau denda, dengan menentukan besaran nilai Singer yang diberikan kepada pelaku yang melanggar hukum adat dayak, akan tetapi sejatinya putusan peradilan adat dayak itu lebih memberikan makna filosofis yakni perdamaian dengan cara melaksanakan ritual adat untuk mengembalikan keseimbangan yang telah rusak akibat pelanggaran hukum adat dayak.

Pada Peraturan Daerah Provinsi Kalimantan Tengah Nomor 16 Tahun 2008 tentang Kelembagaan Adat Dayak Di Kalimantan Tengah Pasal 28 (1) Segala perselisihan, sengketa dan pelanggaran hukum adat yang telah didamaikan dan diberi sanksi adat melalui keputusan Kerapatan Mantir/Let Perdamaian Adat tingkat Kecamatan, adalah bersifat final dan mengikat para pihak. Selanjutnya menurut pada ayat (2) Para pihak yang tidak mengindahkan keputusan adat sebagaimana dimaksud pada ayat (1) dikenakan sanksi adat yang lebih berat oleh karena merusak kesepakatan dan mengganggu keseimbangan yang hidup dalam masyarakat adat. Sedangkan untuk penyelesaian perkara dalam hal ada terjadinya kesulitan didalam pembuktian maka akan dilakukan sumpah adat sebagaimana bunyi ayat (3) Apabila suatu kasus sulit untuk dibuktikan, karena pihak yang disangkakan telah melakukan pelanggaran hukum adat tetapi tidak mau mengakuinya, maka Kerapatan Mantir/Let Perdamaian Adat dapat melakukan upaya terakhir dengan melaksanakan "Sumpah Adat" yang berlaku di wilayah kedamangan bersangkutan. Pada pasal 28 ayat 2 tidak dijelaskan secara lebih rinci hukuman berat seperti apa yang akan diberikan kepada ihak yang tidak melaksanakan putusan adat dayak. Seharusnya ketentuan yang mengatur akibat hukum yang akan diterapkan kepada pihak yang telah dinyatakan bersalah dan mendapatkan putusan adat harus dimuat jelas, seperti dilakukan upaya paksa untuk melakukan ritual adat dayak. Pada Pasal 28 ayat 2 dan ayat 3 memiliki perbedaan makna terkait unsur yang terdapat di dalamnya antara "tidak 
melaksanakan putusan adat" dan "tidak mengakui pelanggarannya sehingga perkara atau kasus menjadi sulit dibuktikan. Pada ayat 3 ini dapat dimaknai bahwa seseorang tidak dapat dibuktikan bersalah karena tidak mengakui telah melakukan perbuatan yang merupakan pelanggaran adat dayak, sehingga putusan adat menjadi sulit untuk dikeluarkan oleh pihak kedamangan, dengan kata lain ayat 3 ini adalah kesulitan di dalam pembuktiannya sedangkan pasal 28 ayat 2 jelas bahwa pelaku telah diputus oleh kedamangan dan mendapatkan putusan adat akan tetapi putusan itu ditolak dan tidak bersedia untuk dipatuhi. Berdasarkan rumusan unsur Pasal 28 ayat 2 dapat dipahami akibat hukumnya adalah sanksi yang lebih berat yang secara otomatis menjadi tugas dan tanggungjawab Damang untuk menginterpretasikan hukuman yang seperti apa yang harus diberikan kepada pelaku. Damang memiliki kewenangan sama halnya seperti hakim dalam memberikan pertimbangan hukum dan memutus perkara, sebagaimana diketahui penemuan hukum oleh hakim sangat diperlukan untuk mengisi kekosongan atau kekaburan hukum. Menurut Sudikno Mertokusumo ${ }^{31}$, interpretasi atau penafsiran hukum salah satu metode penemuan hukum yang memberikan penjelasan gamblang tentang teks undang-undang, agar ruang lingkup kaidah dalam undangundang dapat diterapkan pada peristiwa tertentu. Penemuan hukum ${ }^{32}$ bertujuan untuk memberikan keputusan yang tepat dan benar dan secara tidak langsung memberikan kepastian hukum kepada masyarakat. Penemuan hukum dilakukan apabila suatu peraturan menggunakan istilah yang umum sehingga berakibat lebih dari satu pemaknaan, peraturan tidak jelas atau maknanya kabur dikarenakan perkembangan kenyataan pada masyarakat dan ketiadaan peraturan. Damang dalam hal menyikapi peraturan yang kabur atau belum ada, maka dapat melakukan penemuan hukum layaknya hakim untuk menafsirkan aturan hukum adat baik berupa Perjanjian Damai Tumbang Anoi 1894, asas atau prinsif-prinsif hukum adat dayak berupa prinsif Belom Bahadat, Prinsif Penyang Hinje Simpei, dan filsafat Huma Betang guna menyelesaikan permasalahan tidak dilaksanakannya putusan adat dayak. Penemuan hukum yang dilakukan hakim dalam hukum nasional berdasarkan Pasal 5 (1) Hakim dan hakim konstitusi wajib menggali, mengikuti, dan memahami nilai-nilai hukum dan rasa keadilan yang hidup dalam masyarakat.

Adapun sanksi adat yang terdapat di dalam Peraturan Daerah Provinsi Kalimantan Tengah Nomor 16 Tahun 2008 tentang Kelembagaan Adat Dayak Di Kalimantan Tengah, Bab XI Jenis Sanksi, Pasal 32 Jenis-jenis sanksi yang dapat dijatuhkan oleh Kerapatan Mantir/Let Perdamaian Adat baik di tingkat Desa/Kelurahan maupun di tingkat Kecamatan adalah: a. Nasehat/Teguran secara lisan dan /atau tertulis; b. Pernyataan permohonan maaf secara lisan dan /atau tertulis. c. Singer (nama lain) untuk denda maupun ganti rugi; d. Dikucilkan dari masyarakat adat desa/kelurahan, yaitu pihak pelanggar adat tidak diperbolehkan

\footnotetext{
${ }^{31}$ Ahmad Rifai, "Penemuan Hukum Oleh Hakim Dalam Perspektif Hukum Progresif. Yogyakarta: Sinar Grafika, 2011, hal 61 .

32 Abintoro Prakoso, "Penemuan Hukum," Sistem, Metode, Aliran Dan Prosedur Dalam Menemukan Hukum, 2016, hal. 59.
} 
ikut dalam seluruh kegiatan adat untuk jangka waktu tertentu; e. Dikeluarkan dari masyarakat Desa, yaitu memutuskan semua hubungan sosial dan adat antara masyarakat adat dengan pihak pelanggar dalam jangka waktu tidak terbatas; $f$. Pencabutan gelar adat; g. Dan Iain-lain bentuk sanksi sesuai dengan hukum adat setempat.

Efektifitas peraturan adat tidak terlepas dari beberapa faktor yang salah satunya adalah relevansi aturan hukum dan kebutuhan hukum dari masyarakat ${ }^{33}$. Hukum adat dapat diterapkan secara efektif apabila hukum adat itu pada dasarnya memang sangat dibutuhkan. Masyarakat adat dayak sangat membutuhkan aturan hukum adat yang bisa mengisi kekosongan atau ketiadaan peraturan terkait sanksi atau akibat hukum dari tidak dilaksanakannya putusan adat dayak. Selama ini pelaku dapat dihukum menggunakan hukum adat akan tetapi hukuman itu bisa saja tidak diterapkan karena suatu alasan tertentu atau pihak pelaku menolak dan merasa tidak bersalah, maka aturan hukum adat seperti itu akan sangat tidak efektif, bisa menghukum tapi tidak bisa di eksekusi atau hukuman tidak bisa dilaksanakan. Maka perlu kiranya dirumuskan peraturan terkait sanksi terhadap pelaku yang tidak mau melaksanakan putusan adat dayak dengan catatan peraturan tersebut tetap berdasarkan semangat jiwa masyarakat adat dayak dan berdasarkan nilai-nilai luhur tata kehidupan masyarakat adat dayak.

Sanksi yang berat tidak menjamin putusan peradilan adat dayak dapat terlaksana, melainkan yang tidak kalah penting adalah menumbuhkan rasa kesadaran hukum masyarakat agar patuh dan taat terhadap nilai-nilai luhur dan spiritual dari hukum adat dayak yang ada. Memahami dan merenungi arti penting hukum adat dayak bagi kehidupan masyarakat adat dayak dalam tatanan berbangsa dan bernegara dapat menumbuhkan kesadaran hukum masyarakat. Kesadaran hukum ${ }^{34}$ memiliki arti keadaan ikhlas yang muncul dari hati nurani untuk mengakui dan mengamalkan sesuatu sesuai dengan tuntunan dan tuntutan hukum sehingga melahirkan tindakan dan perasaan yang tumbuh dari hati nurani dan jiwa yang terdalam dari manusia sebagai individu atau masyarakat guna menjalankan pesan-pesan yang terkandung dalam hukum. Kesadaran hukum masyarakat dapat menciptakan ketentraman dan kedamaian sebagaimana filosofi Huma Betang yang memiliki makna kehidupan yang damai, toleransi dalam perbedaan. Empat pilar huma betang meliputi Kejujuran, kesetaraan, kebersamaan dan taat aturan atau disebut dengan "Belom Bahadat" yang memiliki arti hidup bertata krama dan "Belom Penyang Hinje Simpe" memiliki arti hidup dalam kesetaraan, kedamaian, toleransi, kebersamaan. ${ }^{35}$ Pada saat ini putusan peradilan adat dayak selalu dipatuhi dan dijalankan secara suka rela tanpa ada paksaan akan

\footnotetext{
${ }^{33}$ Achmad Ali, "Menguak Teori Hukum (Legal Theory) Dan Teori Peradilan (Judicial Prudence) Termasuk Interprestasi Undang-Undang Legisprudence,” Bandung: Kencana, Cetakan ke 6. 2015, hal. 375-376

${ }^{34}$ Efran Helmi Juni, Filsafat Hukum, Bandung: Pustaka Setia, 2012, hal 407

${ }^{35}$ Anggia Amanda Lukman, "Pewarisan Nilai Sebagai Pembetuk Kepribadian Berkarakter Melalui Falsafah Huma Betang Suku Dayak Kalimantan,” Sosietas 8, No. 1. 2018, hal. 454
} 
tetapi tidak untuk masa yang akan datang putusan peradilan adat dayak bisa saja ada yang menentang dan tidak melaksanakannya sehingga bijak kiranya apabila pengaturan terkait teknis pelaksanaan putusan peradilan adat dayak dibuat untuk mencegah hal yang tidak diinginkan dikemudian hari.

\section{Simpulan}

Pengaturan hukum eksekusi putusan peradilan adat dayak tidak diatur secara tertulis melainkan hidup dan berkembang di dalam prinsif "Belom Bahadat", sehingga pelaksanaan putusan peradilan adat dayak ke depannya harus bisa dirumuskan aturan secara tertulis guna mengisi kekosongan hukum dan menjamin kepastian hukum. Pelaksanaan eksekusi putusan peradilan adat dayak tidak boleh bertentangan dengan hukum nasional dan prinsif "Belom Bahadat". Akibat hukum tidak dilaksanakannya Putusan Peradilan adat dayak secara jasmani kepada pelaku akan diberikan sanksi atau singer yang lebih berat sampai dilakukan pengusiran dari masyarakat adat dayak, akibat hukum religius magisnya adalah rusaknya tatanan kehidupan dan keseimbangan rohani di masyarakat adat dayak karena putusan peradilan adat dayak memuat ritual adat yang diyakini dapat merehabilitasi tatanan keseimbangan kehidupan yang rusak akibat pelanggaran hukum adat. Akibat hukum secara religius magisnya kehidupan pelaku tidak tenang dan akan mendapatkan kesulitan hidup.

\section{Daftar Pustaka}

\section{Buku}

Abintoro Prakoso, "Penemuan Hukum," Sistem, Metode, Aliran Dan Prosedur Dalam Menemukan Hukum, 2016

Achmad Ali, Menguak Teori Hukum (Legal Theory) Dan Teori Peradilan (Judicial Prudence) Termasuk Interprestasi Undang-Undang Legisprudence,” Bandung: Kencana, Cetakan ke 6. 2015

Ahmad Rifai, "Penemuan Hukum Oleh Hakim Dalam Perspektif Hukum Progresif. Yogyakarta: Sinar Grafika, 2011.

Amiruddin, Zainal Asikin. Pengantar Metode Penelitian Hukum Edisi Revisi. Jakarta: Raja Grafindo Persada, 2016.

Bidang Hukum Dan Advokasi Dewan Adat Dayak Kota Palangka Raya. Standar Operasional Prosedur Penyelesaian Sengketa Adat Dayak Di Kota Palangka Raya. Palangka Raya: Dewan Adat Dayak Kota Palangka Raya, 2018.

Biro Pemerintahan Desa Setwilda Tingkat I Kalimantan Tengah. Lembaga Kedamangan Dan Hukum Adat Dayak Ngaju Di Provinsi Kalimantan Tengah. Palangka Raya: Panitia Seminar Dan Lokakarya Kebudayaan Dayak dan Hukum Adat Di Kalimantan Tengah, 1996. 
Darji Darmodiharjo, dan Shidarta. Pokok-Pokok Filsafat Hukum, Apa Dan Bagaimana Filsafat Hukum Indonesia. Jakarta: Gramedia Pustaka Utama Vol. Revisi, 2014.

Dyah, O, and Efendi A'an. Penelitian Hukum (Legal Research)." Jakarta: Sinar Grafika, 2014.

I Dewa Gede Atmadja. Filsafat Hukum Dimensi Tematis Dan Historis. Malang: Setara Press, 2013.

Peter Mahmud Marzuki. Penelitian Hukum: Edisi Revisi. Jakarta: Prenada Media, 2017.

Soekanto Soejono. Pengantar Penelitian Hukum (Edisi Revisi)." Jakarta: UI Press, 2010.

Sudikno Mertokusumo. Penemuan Hukum Sebuah Pengantar. Yogyakarta: Liberty, 2007.

—. Teori Hukum (Edisi Revisi). Jogjakarta: Cahaya Atma, 2012.

Y. Nathan Ilon. Ilustrasi Dan Perwujudan Lambang Batang Garing Dan Dandang Tingang Sebuah Konsepsi Memanusiakan Manusia Dalam Filsafat Suku Dayak Ngaju Kalimantan Tengah. Kapuas: Pemerintah Kabutaten Tingkat II Kapuas, 1987.

Zainuddin Ali. Metode Penelitian Hukum. Edisi 1. Cetakan Ketiga. Jakarta: Sinar Grafika, 2011.

\section{Jurnal}

Citranu. Perjanjian Tumbang Anoi 1894 Sebagai Sumber Hukum Pidana Adat Dayak Ngaju. Tampung Penyang Vol 17 No. 1, 2019: https://doi.org/https://doi.org/10.33363/tampung-penyang.v17i01.395.

I Made Kastama. Hukum Adat Dayak: Bentuk, Penerapan Dan Sanksi Singer Di Desa Pendreh Kecamatan Teweh Tengah Kabupaten Barito Utara. Belom Bahadat 8, no. 2, 2018.

Lilik Mulyadi, Eksistensi Hukum Pidana Adat Di Indonesia: Pengkajian Asas, Norma, Teori, Praktik Dan Prosedurnya, Jurnal Hukum Dan Peradilan 2, no. 2. 2013.

Lukman, Anggia Amanda. Pewarisan Nilai Sebagai Pembetuk Kepribadian Berkarakter Melalui Falsafah Huma Betang Suku Dayak Kalimantan. Sosietas 8, No. 1, 2018.

Luthan, Salman. Dialektika Hukum Dan Moral Dalam Perspektif Filsafat Hukum. Ius Quia Iustum Law Journal 19, No. 4, 2012. 
Nikolas Simanjuntak. Penguatan Lembaga Adat Sebagai Alternatif Penyelesaian Sengketa. Negara Hukum: Membangun Hukum Untuk Keadilan Dan Kesejahteraan 4, No. 1, 2016.

Sonata, Depri Liber. Permasalahan Pelaksanaan Lelang Eksekusi Putusan Pengadilan Dalam Perkara Perdata Dalam Praktik. Fiat Justisia 6, No. 2, 2015.

Sri Hartini, Setiati Widihastuti, and Iffah Nurhayati. Eksekusi Putusan Hakim Dalam Sengketa Perdata Di Pengadilan Negeri Sleman. Jurnal Civics: Media Kajian Kewarganegaraan, 2017. https://doi.org/10.21831/civics.v14i2.16852.

Sri Ismawati. Mekanisme Penyelesaian Perkara Anak Yang Berhadapan Dengan Hukum Pada Masyarakat Dayak Kanayatn (Kajian Perbandingan Terhadap Sistem Peradilan Pidana Anak). Jurnal Dinamika Hukum 13, no. 2. 2013.

Trisno Raharjo. Mediasi Pidana Dalam Ketentuan Hukum Pidana Adat. Ius Quia Iustum Law Journal 17, No. 3, 2010.

Yohanes Ivan. Eksistensi Hukum Pidana Adat Dalam Menangani Delik Adat Pada Masyarakat Hukum Adat Dayak Pangkodan Di Desa Lape Kecamatan Sanggau Kapuas Kabupaten Sanggau Provinsi Kalimantan Barat.” Fakultas Hukum Universitas Atma Jaya. Yogyakarta, 2015.

\section{Peraturan Perundang-undangan}

Undang Undang Nomor 8 Tahun 1981 Tentang Kitab Undang-Undang Hukum Acara Pidana

Undang-Undang Nomor 48 Tahun 2009 Tentang Kekuasaan Kehakiman

Peraturan Daerah Provinsi Kalimantan Tengah Nomor 16 Tahun 2008 tentang Kelembagaan Adat Dayak Di Kalimantan Tengah

Surat Keputusan Damang Nomor: 011/ DKA-KJR/I/2019 tentang Pelaksanaan Putusan Damang di Lingkungan Kedamangan Kecamatan Jekan Raya 